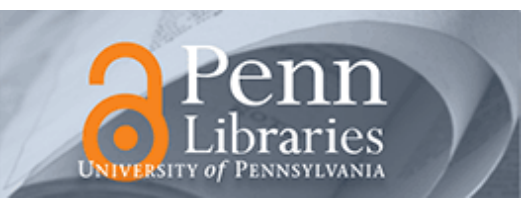

University of Pennsylvania

ScholarlyCommons

Departmental Papers (EES)

Department of Earth and Environmental

Science

January 2005

\title{
The Development Of A Modern Foraminiferal Data Set For Sea- Level Reconstructions, Wakatobi Marine National Park, Southeast Sulawesi, Indonesia
}

\author{
Benjamin P. Horton \\ University of Pennsylvania, bphorton@sas.upenn.edu \\ John E. Whittaker \\ Natural History Museum \\ Katie $\mathrm{H}$. Thomson \\ University of Durham \\ Michael I. J. Hardbattle \\ University of Durham \\ Andrew Kemp \\ University of Durham
}

See next page for additional authors

Follow this and additional works at: https://repository.upenn.edu/ees_papers

\section{Recommended Citation}

Horton, B. P., Whittaker, J. E., Thomson, K. H., Hardbattle, M. I., Kemp, A., Woodroffe, S. A., \& Wright, M. R. (2005). The Development Of A Modern Foraminiferal Data Set For Sea-Level Reconstructions, Wakatobi Marine National Park, Southeast Sulawesi, Indonesia. Retrieved from https://repository.upenn.edu/ ees_papers/49

Postprint version. Published in Journal of Foraminiferal Research, Volume 35, Number 1, January 2005, pages 1-14.

This paper is posted at ScholarlyCommons. https://repository.upenn.edu/ees_papers/49

For more information, please contact repository@pobox.upenn.edu. 


\title{
The Development Of A Modern Foraminiferal Data Set For Sea-Level Reconstructions, Wakatobi Marine National Park, Southeast Sulawesi, Indonesia
}

\author{
Abstract \\ We collected modern foraminiferal samples to characterize the foraminiferal environments and \\ investigate the role that temporal and spatial variability may play in controlling the nature and significance \\ of foraminiferal assemblages of the mangroves of Kaledupa, Wakatobi Marine National Park, Southeast \\ Sulawesi, Indonesia. The study of foraminiferal live and dead assemblages indicates that dead \\ assemblages are least prone to vary in time and space, and furthermore, they accurately represent the \\ subsurface assemblages that are the focus of paleoenvironmental reconstructions. \\ Further analyses of the dead assemblages indicate a vertical zonation of foraminifera within the intertidal \\ zone. Zone D-la is dominated by agglutinated foraminifera Arenoparrella mexicana, Miliammina fusca, $M$. \\ obliqua and Trochammina inflata. Zone D-Ib has mixed agglutinated/calcareous assemblages with \\ species such as $T$. inflata and Ammonia tepida. Zone D-II is dominated by numerous calcareous species \\ including A. tepida, Discorbinella bertheloti, Elphidium advenum and Quinqueloculina spp. Zone D-la is \\ found to be the most accurate sea-level indicator and its assemblages are omnipresent world-wide. \\ Zones D-Ib and D-II are subject to both spatial and temporal variations which must be included in any sea- \\ level reconstructions.

\section{Comments} \\ Postprint version. Published in Journal of Foraminiferal Research, Volume 35, Number 1, January 2005, \\ pages $1-14$.

\section{Author(s)} \\ Benjamin P. Horton, John E. Whittaker, Katie H. Thomson, Michael I. J. Hardbattle, Andrew Kemp, Sarah A. \\ Woodroffe, and Matthew R. Wright
}




\title{
The development of a modern foraminiferal data set
}

\section{for sea-level reconstructions, Wakatobi Marine National Park, Southeast Sulawesi, Indonesia}

\author{
Benjamin. P. Horton ${ }^{1 *}$, John E. Whittaker ${ }^{2}$, Katie. H. Thomson ${ }^{3}$, \\ Michael I. J. Hardbattle ${ }^{3}$, Andrew Kemp ${ }^{3}$, Sarah. A. Woodroffe ${ }^{3}$ and \\ MATTHEW R. WRIGHT ${ }^{3}$
}

RRH: FORAMINIFERA OF INDONESIA

LRH: BP HORTON AND OTHERS

${ }^{1}$ Department of Earth and Environmental Science, University of Pennsylvania, Philadelphia, PA 19104-6316, USA.

${ }^{2}$ Micropaleontology Research, Department of Palaeontology, The Natural History Museum, London, SW7 5BD, UK.

${ }^{3}$ Department of Geography, University of Durham, South Road, Durham, DH1 3LE, UK.

* Corresponding author: Tel: 215898 5725; Fax: 215898 0964; E-mail: XXXX@sas.upenn.edu. 


\begin{abstract}
We collected modern foraminiferal samples to characterize the foraminiferal environments and investigate the role that temporal and spatial variability may play in controlling the nature and significance of foraminiferal assemblages of the mangroves of Kaledupa, Wakatobi Marine National Park, Southeast Sulawesi, Indonesia. The study of foraminiferal live and dead assemblages indicates that dead assemblages are least prone to vary in time and space, and furthermore, they accurately represent the subsurface assemblages that are the focus of paleoenvironmental reconstructions.

Further analyses of the dead assemblages indicate a vertical zonation of foraminifera within the intertidal zone. Zone D-la is dominated by agglutinated foraminifera Arenoparrella mexicana, Miliammina fusca, M. obliqua and Trochammina inflata. Zone D-Ib has mixed agglutinated/calcareous assemblages with species such as $T$. inflata and Ammonia tepida. Zone D-II is dominated by numerous calcareous species including $A$. tepida, Discorbinella bertheloti, Elphidium advenum and Quinqueloculina spp. Zone D-la is found to be the most accurate sea-level indicator and its assemblages are omnipresent world-wide. Zones D-Ib and D-II are subject to both spatial and temporal variations which must be included in any sea-level reconstructions.
\end{abstract}




\section{INTRODUCTION}

The recent transition of the earth climate system from a glacial to interglacial state produced a dramatic global sea-level response. Regions distant from the major glaciation centers, known as far-field sites, are typically characterized by relative sealevel (RSL) rise of $\sim 120 \mathrm{~m}$ since the last glacial maximum (LGM) due, largely, to the influx of glacial meltwater to the oceans. In contrast, RSL dropped by many hundreds of meters in regions once covered by the major ice sheets (near- and intermediate-field sites) as a consequence of the isostatic 'rebound' of the solid Earth (Lambeck and others, 2002; Peltier and others, 2002; Shennan and others, 2002). Field observations of RSLs from far field locations provide essential constraints to geophysical models because model predictions depend upon three mechanisms: ocean siphoning caused mainly by gravitational effects due to the collapse of peripheral forebulges (Mitrovica and Peltier 1991); continental levering associated with local ocean loading; and global ice melt since the LGM (magnitude and source).

Although much contemporary research to test such theoretically derived models has focused on data sets from near- and intermediate-field sites (e.g., Shennan and others, 2000; Shennan and Horton, 2002), it is widely recognized that far-field sites provide the best possible estimate of the 'eustatic function' (Clark and others, 1978; Fleming and others, 1998; Yokoyama and others, 2001; Peltier, 2002). Consequently, model-derived reconstructions are increasingly recognizing the importance of these areas to constrain and test their geophysical earth models. With notable exceptions (Fairbanks, 1989, 1990; Bard and others, 1996; Chappell and others, 1998; Nunn and Peltier, 2001; Yokoyama and others, 2001), few studies have examined the sea-level histories from tectonically stable far-field areas. Furthermore, much of the data is derived from cored corals, which 'are not the clear indicators of past sea-levels that they are 
sometimes suggested to be' (Hopley, 1986). Problems encountered focus on the large elevational range exhibited by some coral species and the delayed response of a reef system to the sea-level change. Consequently, this study of Wakatobi Marine National Park, Southeast Sulawesi, Indonesia, which is a tectonically stable far-field site, begins to address the need to acquire accurate sea-level indicators (e.g., foraminifera) in locations away from major plate boundaries.

Many researchers have used foraminiferal distributions across the intertidal zone of temperate saltmarshes as sea-level indicators (e.g., Scott and Medioli, 1978, 1980a; Patterson, 1990; Gehrels, 1994; de Rijk, 1995; Horton, 1999; Horton and others, 1999a b; Gehrels and others, 2001). The intertidal distributions can be divided into two parts: an agglutinated assemblage that is restricted to the vegetated marsh; and a calcareous assemblage that dominates the mudflats and sandflats of the intertidal zone. The agglutinated assemblage is commonly employed as a sea-level indicator in the reconstruction of former sea levels. Saltmarsh foraminiferal zonation is a significantly more accurate indicator of sea level than undifferentiated marsh deposits since welldefined zones subdividing the marsh increase the vertical resolution of the deposits (Scott and Medioli, 1978). Furthermore, Scott and others (2001) state that vertical zonations are observed in marshes throughout the world, and suggest that marsh foraminifera are ubiquitous worldwide. However, studies of microfossils and their relationship to RSL in coastal and estuarine environments from tropical or subtropical environments to support this conclusion are sparse, indeed, non-existent for Indonesia. Thus, this paper seeks to document, for the first time, some characteristics of modern foraminiferal environments in the central Wakatobi Marine National Park province for use in paleoenvironmental interpretations made from Quaternary sediments of Indonesia.

This paper also discusses which assemblage constituents (live, dead and/or total) are best applied for foraminiferal-based sea-level reconstructions studies in tropical 
locations and investigates the role that temporal and spatial variability may play in controlling the nature and significance of foraminiferal assemblages. Many researchers state that total assemblages most accurately represent general environmental conditions because they integrate seasonal and temporal fluctuations (e.g., Scott and others, 2001). However, Murray $(1991,2000)$ suggests that the use of total assemblages disregards changes that will affect live assemblages after their death. Furthermore, depositional changes are sample dependent because the greater the vertical depth of a sample, the more important the dead contribution. Horton (1999) indicates that the dead assemblages from temperate marshes are the most appropriate for paleoenvironmental studies because these assemblages are less susceptible to seasonal variations and closely resemble subsurface assemblages. Horton (1999) and Horton and Edwards (2003) concluded that if the live assemblages are variable and not transferred into subsurface environments, their combination with the dead assemblage to produce a total assemblage simply degrades the utility of the latter. Thus, in this paper we have only investigated the live and dead assemblages.

\section{STUDY AREA}

Extending over $13,900 \mathrm{~km}^{2}$, the Wakatobi Marine National Park includes all coral reefs, islands, and communities within its boundaries and is centered around the main islands in the Wakatobi archipelago (Fig. 1). The area is considered 'a geological and biological anomaly' (Daws and Fujita, 1999) and is located at a zone of transition between the two distinct faunas associated with the Asian and Australian continents. Wallace (1869) postulated that the islands of Sulawesi had been isolated far longer than the surrounding islands, giving evolution a much greater opportunity to shape a unique fauna. 
The field site is located on a tidal mangrove creek system on the northern coast of the island of Kaledupa (Fig. 1B). At the mouth of the creek, and along much of the coast of Kaledupa, is a $150 \mathrm{~m}$-wide fringing mangrove swamp, with vegetation up to $7 \mathrm{~m}$ in height. The mangroves of Kaledupa exhibit a pronounced zonation of species similar to many other mangrove swamps (e.g., Chapman, 1944, Macnae, 1968; Snedaker, 1982) with a fringing Rhizophora zone, transgressing into a mixed Rhizophora/Sonneratia zone and then an Avicennia mangrove zone (Barnes, written communication, 2002). The landward edge of the mangrove environment terminates on an exposed coral terrace. Tides in the area are semi-diurnal and microtidal, with mean spring tidal ranges of $1.6 \mathrm{~m}$. On the flood tide, water enters the mangroves and saltflats via a network of small channels.

\section{METHODOLOGY}

Samples of surface sediment were collected from 20 stations along two $160 \mathrm{~m}$ transects $(A$ and $B)$. Both transects cross the intertidal zone from an exposed former coral terrace through a mangrove swamp and onto an unvegetated intertidal mudflat. All stations were leveled to sea level using a level and staff at regular spatial and temporal intervals throughout the study, and the tidal curve from Boeton Island was used to calculate elevations with respect to Indonesian Height Datum (IHD). At each station, one sample of approximately $10 \mathrm{~cm}^{3}$ volume $\left(10 \mathrm{~cm}^{2}\right.$ surface sample by $1 \mathrm{~cm}$ thick) was taken for foraminiferal analysis.

To investigate the role that temporal and spatial variability may play in controlling the nature and significance of foraminiferal assemblages, samples were taken twice during a two-month period (Transects A1 and A2) and once from an additional adjacent transect (Transect B). Foraminiferal sample preparation followed Scott and others (2001). The species were identified with reference to a number of publications, namely 
Collins (1958), Albani (1968), Albani and Yassini (1993), Brönnimann and Whittaker (1993), Yassini and Jones (1995), Hayward and others (1999a) and Revets (2000), and by study of reference collections in the Natural History Museum, London (Plate 1). Samples were stored in buffered ethanol with protein stain Rose Bengal to identify organisms living at the time of collection, and thus allow the analyses of live and dead assemblages (Walton, 1952; Scott and Medioli, 1980b; Murray, 1991; Murray and Bowser, 2000).

We used two multivariate methods to detect, describe and classify patterns within the live and dead foraminiferal data set: unconstrained cluster analysis and detrended correspondence analysis (DCA). Unconstrained cluster analysis based on the unweighted Euclidean distance, using no transformation or standardization of the percentage data, was used to classify modern samples into more-or-less homogeneous faunal zones (clusters). Detrended correspondence analysis, an ordination technique, was used to represent samples as points in a multidimensional space. Similar samples are located together and dissimilar samples apart. Thus, cluster analysis is effective in classifying the samples according to their foraminiferal assemblage but, DCA gives further information about the pattern of variation within and between groups. This is important, as the precise boundaries between clusters can be arbitrary. Thus, we selected reliable faunal zones when the samples within each cluster were mutually exclusive in ordination space. The elevation of each station within the reliable clusters determined the vertical zonation of each intertidal environment.

We employed Student's T-Test to determine whether two samples from A1 and $A 2$, and $A 1$ and $B$ are likely to have come from the same two underlying populations. We use a two-tailed distribution. 


\section{RESULTS}

Forty species of foraminifera were identified from the study of surface samples from the mangroves of Kaledupa. The maximum number of species per $10 \mathrm{~cm}^{3}$ sample was 23 , with maximum and minimum foraminiferal total (live plus dead) abundance of 632 and 134 individuals per sample, respectively. The live and dead assemblages are dominated by three agglutinated species, Arenoparrella mexicana, Miliammina fusca, and Trochammina inflata, and four calcareous species, Ammonia tepida, Discorbinella bertheloti, Elphidium advenum and Quinqueloculina spp.

\section{LIVE ASSEMBLAGES}

The live assemblage of Transect A1 is dominated by calcareous species, which represent over $75 \%$ of the total count. Calcareous taxa such as A. tepida, E. advenum, D. bertheloti, and Q. spp. dominate the unvegetated mudflat and fringing Rhizophora mangrove section of the transect ( $0-60 \mathrm{~m}$ along the transect). Maximum percentages of E. advenum (15\%), A. tepida (30\%) and D. bertheloti (13\%) occur $0 \mathrm{~m}, 18 \mathrm{~m}$ and $40 \mathrm{~m}$ along the transect, respectively (Fig. 2). In addition, the Rhizophora floral zone has a relatively high foraminiferal abundance, with an average count of 253 live specimens per $10 \mathrm{~cm}^{3}$. The Rhizophora/Sonneratia floral zone (60 - $90 \mathrm{~m}$ along the transect) is also dominated by calcareous species with the maximum percentage of Haynesina depressula occurring within this zone (12\%). However, there is an increasing agglutinate presence, in particular $T$. inflata, which reaches $22 \% 90 \mathrm{~m}$ along the transect. The majority of calcareous species are replaced by agglutinated species within the Avicennia mangrove zone (90 - $160 \mathrm{~m}$ along the transect). However, maximum percentages of $Q$. spp. (71\%) occur $120 \mathrm{~m}$ along the transect. The maximum percentage of the dominant 
agglutinated taxa T.inflata, M. fusca, and A. mexicana occur within this Avicennia zone (24\%, 41\% and $16 \%$, respectively).

The total number of live foraminifera from the twenty stations of the Transect A1 is 3648 compared to 4102 specimens for the temporal Transect A2 (taken 2 months later). There are also differences in the dominant live foraminiferal species (Fig. 3). The relative contribution of $Q$. spp. between 5 and $32 \mathrm{~m}$ along the transect is greater than $30 \%$ at each sampling station of Transect A1 compared to less than $19 \%$ for Transect A2. Furthermore, $90 \mathrm{~m}$ along the transect the relative contributions of $Q$. spp. are $44 \%$ on $\mathrm{A} 1$ to $15 \%$ on $\mathrm{A} 2$, whereas $105 \mathrm{~m}$ along the transect $\mathrm{A} 1$ is $8 \%$ and $\mathrm{A} 2$ is $30 \%$. Indeed, T-tests suggest that the relative abundances of $Q$. spp. between transects A1 and $\mathrm{A} 2$ are statistically significantly different and did not come from the same underlying population (Table 1). Other notable differences include lower percentages of $T$. inflata between $128 \mathrm{~m}$ and $150 \mathrm{~m}$ along the transect for $\mathrm{A} 1(<16 \%)$ compared to Transect $\mathrm{A} 2$ (>26\%), and appreciably lower percentages of $A$. mexicana at the landward edge of the transect (5\% on $\mathrm{A} 1$ to $56 \%$ on $\mathrm{A} 2)$.

The total number of live foraminifera also increases from the original transect (A1) to spatial Transect B (4057 specimens) taken adjacent to A1. The difference in contribution of $Q$. spp. between transects is amplified $90 \mathrm{~m}$ along the transect $(44 \%$ on A1 to $6 \%$ on $B$ ), whereas $105 \mathrm{~m}$ along the transect $A 1$ is $8 \%$ and $B$ is $44 \%$ (Fig. 4). Other notable dissimilarities include the increase in relative abundance of $M$. fusca $150 \mathrm{~m}$ along the transect ( $13 \%$ on $\mathrm{A} 1$ to $44 \%$ on $\mathrm{B})$ and a corresponding decrease in $A$. mexicana (41\% on A1 to $19 \%$ on B). Statistical analyses (T-tests) support the inference that these three species show significantly different assemblages between transects $A 1$ and B (Table 1). 


\section{DEAD ASSEMBLAGES}

There is an increase in the relative abundance of agglutinated foraminifera in the dead assemblage, with agglutinated species contributing over $35 \%$ to the total dead assemblage of Transect A1. However, the unvegetated mudflat and fringing mangrove floral zones are dominated by calcareous foraminifera such as $A$. tepida, E. advenum, $D$. bertheloti, H. depressula and Q. spp., with the two most dominant species reaching their maximum abundance within this zone (A. tepida - 30\% and Q. spp. 37\%). The unvegetated mudflat and fringing mangrove have the highest foraminiferal counts within the intertidal zone with an average count of 216 dead species per $10 \mathrm{~cm}^{3}$ (Fig. 5).

The Rhizophora/Sonneratia mangrove zone shows an increasing contribution of agglutinated species, most notably $T$. inflata. However, $A$. tepida contributes at least $16 \%$ at each station and the zone still possesses the maximum abundances of numerous calcareous species, including $A$. takanabensis and $H$. depressula $(28 \%$ and $14 \%$, respectively). Nevertheless, the tendency of the increasing contribution of agglutinated species continues within the Avicennia mangrove zone, which is dominated by agglutinated species such as T.inflata, M. fusca, M. obliqua and A. mexicana; agglutinated species make up at least $65 \%$ of the assemblage landwards of $105 \mathrm{~m}$.

The foraminiferal dead assemblage count is relatively stable among the original (A1), temporal (A2) (Fig. 6) and spatial (B) (Fig. 7) transects. The total number of dead foraminifera is also relatively constant; 3712 on A1, 3708 on A2 and 3955 specimens on B. Statistical analyses do not show any significant differences although there are noteworthy differences at individual stations (Table 1). For example, the relative contribution of $A$. mexicana fluctuates from $12 \%$ on $A 1$ to $32 \%$ on $A 2$, and $48 \%$ on $A 1$ to $12 \%$ on $\mathrm{A} 2$ at $120 \mathrm{~m}$ and $150 \mathrm{~m}$ along the transect, respectively. 


\section{DISCUSSION}

There is much debate about which foraminiferal assemblage constituents (live, dead and/or total) to use for sea-level reconstructions (Buzas, 1968; Scott and Medioli, 1980b; Scott and Leckie, 1990; de Rijk, 1995; Murray, 2000; Scott and others, 2001). These studies have, however, concentrated on foraminiferal species from temperate intertidal areas. This new study assesses the applicability of live and dead assemblages from tropical environments. Analyses of the spatial and temporal variations of the dominant species show that the dead assemblages are less susceptible to temporal and spatial variations compared to live counterparts. We investigated this further by examining the differences in the vertical zonation of the live and dead assemblage. Figures 8 and 9 both show the combined foraminiferal data (original A1, temporal A2 and spatial B transects) of the live and dead assemblages separated into three reliable zones by cluster analysis and DCA. The live assemblages do not show any vertical zonations due to the heterogeneity of living assemblages in space and time, in particular Zone L-Ib, which covers the full elevational range of the transects. Similar spatial and temporal variations have been documented by many studies (Buzas, 1968; Schafer, 1968; Jones and Ross, 1979; Schafer and Mudie, 1980; Alve and Murray, 1999, 2001; Murray and Alve, 2000; Swallow, 2000; Buzas and others, 2002; Hippensteel and others, 2002; Horton and Edwards, 2003). Schafer and Mudie (1980) discovered an order of magnitude difference in average foraminiferal number between pairs of sites. Alve and Murray (2001) demonstrated significant temporal variability over a 27-month period with the number of species found at any single sampling event varying between 5 and 22. Such temporal and spatial patterns of live assemblages reflect the impact of factors such as seasonality, predation, reproduction, mode, sources and distribution 
pattern of food particles and species interactions (Buzas, 1968; Schafer, 1968; Scott and others, 2001).

In contrast to the live assemblages, the dead assemblages present a more homogeneous spatial and temporal distribution as a probable consequence of postmortem lateral and vertical mixing of empty tests by biological and physical agents (Scott and others, 2001). The dead assemblages assimilate all temporal variation and spatial patchiness into an 'average signal' that tends to reduce the inter-sample variance. For example, the combined dead assemblages are classified into three reliable zones that show a strong vertical zonation (Fig. 9), which indicates that the distribution of dead foraminifera are a direct function of elevation, with the duration and frequency of intertidal exposure as the most important environmental factors.

Agglutinated species A. mexicana, M. fusca, M. obliqua and T. inflata dominate Zone D-la, which is found at the landward edge of the mangrove study site with an elevational range of 2.02 - $1.02 \mathrm{~m} \mathrm{IHD} \mathrm{(range} 0.20 \mathrm{~m}$ ). Similar faunal assemblages have been observed at the landward margins of both tropical mangroves and temperate saltmarshes. Brönnimann and others (1992) and Brönnimann and Whittaker (1993) found assemblages of $A$. mexicana in mangrove sediments of the Fiji and Malay archipelagos, respectively. Assemblages dominated by $T$. inflata have been identified by Haslett (2001) and Horton and others (2003) at the landward limit of mangrove distributory channels from the Great Barrier Reef coastline, Australia. Many studies have identified high abundances of M. fusca in the mangroves of Fiji, southwest Australia, Brazil, New Zealand, northern Australia and the Great Barrier Reef coastline (Brönnimann, and others, 1992; Bronnimann and Whittaker, 1993; Yassini and Jones, 1995; Debenay and others, 1998, 2000; Hayward and others, 1999a, b; Wang and Chappell, 2001; Horton and others, 2003). Studies of temperate saltmarshes have commonly identified a high marsh zone dominated by $T$. inflata and a low marsh zone 
dominated by M. fusca (Scott and Medioli, 1978, 1980a; Gehrels, 1994; Horton, 1999; Horton and others, 1999a; Spencer, 2000; Hippensteel and others, 2000; Horton and Edwards, 2003, 2004 in press).

Faunal Zone D-Ib has a mixed agglutinated/calcareous assemblage composed of Ammonia species, with lower frequencies of $T$. inflata and $M$. obliqua. The zone ranges from $1.90-1.60 \mathrm{~m}$ IHD (range $0.30 \mathrm{~m}$ ). Other tropical and temperate studies have observed mixed agglutinated/calcareous assemblage zones but with an increase in the relative abundance of the former (Scott and Medioli, 1978, 1980a; Gehrels, 1994; Yassini and Jones, 1995; Debenay and others, 1998, 2000; Hayward and others, 1999a,b ; Wang and Chappell, 2001; Horton and Edwards, 2003; Horton and others, 2003).

Zone D-II is found at the seaward edge of the transects and is dominated by numerous calcareous species such as $A$. tepida, D. bertheloti, E. advenum and Q. spp., with a relatively large elevation range of $1.71-0.47 \mathrm{~m} \mathrm{IHD} \mathrm{(range} 1.24 \mathrm{~m}$ ). Other calcareous faunal zones with relatively high abundances of $A$. tepida are common in many tropical or subtropical locations (Hayward and others, 1996; Debenay and others, 2000; Wang and Chappell 2001; Horton and others, 2003), although there are many species that are site specific. For example, studies of tidal flat environments of the Great Barrier Reef coastline by McIntyre (1997) and Horton and others (2003) have identified a foraminiferal faunal zone dominated by cosmopolitan Ammonia species, in addition to Miliolinella spp., the endemic E. discoidale multiloculum and extinct Pararotalia venusta. The presence of $P$. venusta indicates some reworking of material within the intertidal zone of this study site. Analyses of temperate saltmarshes show differences from the Kaledupan transect. Studies of British saltmarshes display tidal flat assemblages dominated by Haynesina germanica and other Elphidium species (Horton, 1999; 
Edwards and Horton, 2000; Murray and Alve, 2000; Gehrels and others, 2001; Horton and Edwards, 2003, 2004 in press).

\section{IMPLICATIONS FOR SEA-LEVEL STUDIES}

The understanding of former sea levels based on the identification and interpretation of foraminiferal assemblages requires that their indicative meaning is known, i.e., the vertical relationship of the local environment in which the assemblage accumulated to a reference tide level (van de Plassche, 1986; Shennan, 1986; Horton and others, 1999b; 2000). The indicative meaning is commonly expressed in terms of an indicative range and a reference tidal level, the former being a vertical range within which the assemblage can occur, and the latter a tidal level to which the assemblage is assigned, e.g., mean high high water (MHHW) (Fig. 10).

Estimates of the indicative meaning of faunal zones from the mangroves of Kaledupa (Table 2) are developed from the premise that zones found vertically adjacent, without a hiatus, must have formed in environments that existed side by side in space (Walthers Law). Therefore, the transition from faunal Zone D-Ib to Zone D-II has an indicative range equal to the range of the transition from one zone to the other, not that of the individual zone. For example, the indicative range of Zone D-II is $\pm 0.62 \mathrm{~m}$, whereas the range of Zone D-Ib directly above Zone D-II is only $\pm 0.06 \mathrm{~m}$. The ranges cover the elevational limits of the boundary when observed during the 2 sampling months.

Despite the conclusion that dead assemblages are less variant than live assemblages in most spatial and temporal fluctuations, it is important to identify any variations in the vertical zonation that must be included in any sea-level reconstruction to avoid errors in accuracy and precision (Horton and Edwards, 2003). Multivariate 
analyses of each individual transect ( $A 1, A 2$ and $B)$ show that the elevational range of the Zone D-la remains virtually constant; however, spatial and temporal variations in the dead assemblages are observed for faunal zones D-Ib and D-II (Fig. 11). The elevation of the boundary between zones D-Ib and D-II fluctuates from $1.86 \mathrm{~m}$ IHD at A1 to $1.42 \mathrm{~m}$ IHD at $B$, suggesting that some of the variability in the live assemblages is being transmitted to the dead assemblages.

In addition to spatial and temporal variations, it is also important for sea-level reconstructions to assess the influence of post-depositional processes on the assemblage constituents. Thus, subsurface dead assemblages, the focus of paleoenvironmental reconstructions, were collected from the mudflat, fringing Rhizophora, mixed Rhizophora/Sonneratia and Avicennia environments to determine which modern assemblage constituents are most appropriate for paleoenvironmental reconstruction. Subsurface samples were collected at a depth of $12 \mathrm{~cm} ; 97 \%$ of live specimens occurred above this depth. Scatter plots (Fig. 12) show a clear positive linear correlation between the subsurface and surface dead assemblages $\left(r^{2}=0.90\right)$ from Transect A1. The dead assemblages fluctuate little between the subsurface and surface because calcareous species such as $Q$. spp. are relatively minor contributors to surface dead assemblages in mangrove environments. In contrast, the live assemblages $\left(r^{2}=\right.$ 0.29) show little relationship to subsurface dead assemblages. The live assemblages of the surface samples incorporate live calcareous species, which can represent over $85 \%$ of the assemblage from mangrove floral zones. However, post-depositional changes result in calcareous species being removed and the subsurface assemblages become more dominated by agglutinated species. Calcareous tests can be rapidly destroyed after death through dissolution in acidic pore waters (Green and others, 1993). 


\section{CONCLUSIONS}

The study of foraminiferal dead assemblages of the mangroves of Kaledupa indicates that the assemblage accurately represents the subsurface assemblages which are the focus of paleoenvironmental reconstructions, and furthermore that they do not show spatial and temporal fluctuations as much as the live assemblages. Statistical analyses of the dead assemblages support numerous studies from temperate or tropical regions that indicate a vertical zonation of foraminifera within the intertidal zone: Agglutinated foraminifera such as A. mexicana, T. inflata, and M. fusca dominate Zone D-la; Zone D-lb contains a mixed agglutinated/calcareous assemblages with species such as T. inflata and A. tepida; and Zone D-II is dominated by numerous calcareous species. Zone D-la is found to be the most accurate sea-level indicator and its assemblages are omnipresent world-wide. Zone D-Ib and D-II are subject to both spatial and temporal variations, which must be incorporated into any sea-level reconstructions.

A data repository of all foraminiferal (percentage and raw counts) and environmental data can be found on the following website: http://www.geography.dur.ac.uk/information/official_sites/bph.html

\section{ACKNOWLEDGMENTS}

The authors thank all staff of Operation Wallacea Ltd., in particular, Richard Barnes, Tim Coles, Dave Smith, Steve Mcmellor, Steve Oliver and Magnus Johnson. We acknowledge and greatly appreciate the funding by Operation Wallacea Ltd and the University of Durham's Council Fund for Students Traveling Abroad. The authors also 
thank Andy Kemp, John Metcalfe, Andy Fenton, James Kahane, Dave Taylor and Katie White for their skills in the field, and David Blackman, Proudman Oceanographic Laboratory, for tidal predictions for Indonesian Ports. The authors also wish to express their gratitude for the help and support given by the Department of Geography, University of Durham and the Natural History Museum, London. In particular the authors would like to thank the two reviewers, Robin Edwards and Bruce Hayward and the editor, Laurel Collins, for their help and advice.

\section{REFERENCES}

AlbANI, A.D., 1968, Recent foraminifera from Port Hacking, New South Wales: Contributions from the Cushman Foundation for Foraminiferal Research, v. 19, p. 85-119.

— (Foraminiferida) from shallow Australian waters: University of New South Wales Centre for Marine Science, Technical Contribution Number 5. p51.

AlVE, E., and MURRAY, J.W., 1999, Marginal marine environments of the Skagerrak and Kattegat: a baseline study of living (stained) benthic foraminiferal ecology: Palaeogeography, Palaeoclimatology, Palaeoecology, v. 146, p. 171-193.

$\longrightarrow$, and,- 2001, Temporal variability in vertical distributions of live (stained) intertidal foraminifera, southern England: Journal of Foraminiferal Research, v. $31, \mathrm{p} 2-11$.

Bard, E., hamelin, B., Arnold, M., Montaggioni, L., Cabioch, G., Faure, G., and Rougerie, F., 1996, Deglacial sea-level record from Tahiti corals and the timing of global meltwater discharge: Nature, v. 382, p. 241-244. 
BRÖNNIMANN, P., WhitTAKER, J.E., and ZANINETTI, L., 1992, Brackish water foraminifera from mangrove sediments of southwestern Viti Levu, Fiji Islands, Southwest Pacific: Revue de Paléobiologie, v. 11, p. 13-65.

$\longrightarrow$, and -1993 , Taxonomic revision of some recent agglutinated foraminifera from the Malay Archipelago in the Millett Collection: Bulletin of the Natural History Museum, London (Zoology), v. 59, p.107-124.

BuZAS, M.A., 1968, On spatial distribution of foraminifera: Contributions from the Cushman Foundation Foraminiferal Research, v. 19, p. 1-11.

—, HAYAK, L.-A.C., ReEd, S.A., and JeTt, J.A., 2002, Foraminiferal densities over five years in the Indian River Lagoon, Florida: A model of pulsating patches: Journal of Foraminiferal Research, v 32, p 68-92.

Chapman, V.J., 1944, The Cambridge University expedition to Jamaica. Part 1. A study of the botanical processes concerned in the development of the Jamaican shore line: Botanical Journal of the Linnean Society, v. 52, p. 407-447.

Chappell, J., OTA, Y., and CAMPBelL, C., 1998. Decoupling post-glacial tectonism and eustasy at Huon Peninsula, Papua New Guinea: Geological Society Special Publication, v. 146, p. 31-40.

Clark, J. A., Farrell, W.E., and Peltier, W.R., 1978, Global changes in post glacial sea level: a numerical calculation: Quaternary Research, v. 9, p. 265-287.

ColliNS, A.C., 1958. Foraminifera: Scientific Reports of the Great Barrier Reef Expedition 1928-29, v. 6, p. 335-437.

DAWS, G., and FuJITA, M., 1999, Archipelago: the Islands of Indonesia: from the Nineteenth Century Discoveries of Alfred Russell Wallace to the Fate of Forests and Reefs in the Twenty-first Century: University of California Press, Berkeley, 254 pp. 
Debenay, J-P., Eichler, B., Beck, Duleba, W., Bonetti, C., and Eichler-Coelho, C., 1998. Stratification in coastal lagoons: Its influence on foraminiferal assemblages in two Brazilian lagoons: Marine Micropaleontology, v. 35, p. 65-89.

—, Guillou, J.-J., Redois, F., and Geslin, E., 2000, Distribution trends of foraminiferal assemblages in paralic environments. In: Martin, R.E (Ed.) Environmental Micropaleontology, Volume 15 of Topics in Geobiology: Kluwer Publishers, New York, p. 39-67.

EdWARds, R.J., and HORTON, B.P., 2000, High Resolution Records of Relative SeaLevel Change from U.K. Salt-marsh Foraminifera: Marine Geology, v. 169, p. 4156.

FAIRBANKS, R.G., 1989, A 17,000-year glacio-eustatic sea level record: influence of glacial melting rates on the Younger Dryas event and deep-ocean circulation: Nature, v. 342, p. 637-642.

- 1990, The age and origin of the 'Younger Dryas climate event' in Greenland ice cores: Paleoceanography, v. 5, p. 937-948.

Fleming, K., Johnston, P., ZWARTZ, D., Yokoyama, Y., LAmBeCK, K., and ChAPPell, J., 1998, Defining the eustatic sea-level curve since the last glacial maximum using far and intermediate-field sites: Earth and Planetary Science Letters, v. 163, p. $327-342$.

GEHRELS, W.R., 1994, Determining relative sea-level change from saltmarsh foraminifera and plant zones on the coast of Maine, USA: Journal of Coastal Research, v. 10, p. 990-1009.

- RoE, H.M., and ChARMAN, D.J., 2001, Foraminifera, testate amoebae and diatoms as sea-level indicators in UK saltmarshes: a quantitative multiproxy approach: Journal of Quaternary Science, v. 16, p. 201-220. 
Green, M. A., Aller, R. C. and Aller, J. Y., 1993, Carbonate dissolution and temporal abundances of foraminifera in Long Island Sound sediments: Limnology and Oceanography, 38, p. 331-345.

HASLETT, S.K., 2001, The Palaeoenvironmental implications of the distribution of intertidal foraminifera in a tropical Australian estuary: a reconnaissance study: Australian Geographical Studies, v. 39 (1), p. 67-74.

Hayward, B.W., GRenfell, H., CAIRNS, G., and SMITH, A., 1996, Environmental controls on benthic foraminifera and thecamoebian associations in a New Zealand tidal inlet: Journal of Foraminiferal Research, v. 38, p. 249-259.

,-- , REID, C.M., and HAYWARD, K.A., 1999a, Recent New Zealand shallow water benthic foraminifera: taxonomy, ecological distribution, biogeography, and use in palaeoenvironmental assessment: Institute of Geological and Nuclear Science Ltd, Lower Hutt, New Zealand.

- - - and ScotT, D.B., 1999b, Tidal range of marsh foraminifera for determining former sea-level heights in New Zealand: New Zealand Journal of Geology and Geophysics, v. 42, 395-413.

Hippensteel, S.P., MARtin, R.E., NikitinA, D., and PizzUto, J. , 2000, The formation of Holocene marsh foraminiferal assemblages, middle Atlantic Coast, U.S.A.: implications for Holocene sea-level change: Journal of Foraminiferal Research, v. 30 , p. 272-293.

,-- , and,- 2002 , Interannual variation of marsh foraminiferal assemblages (Bombay Hook National Wildlife Refuge Smyrna, DE): Do foraminiferal assemblages have a memory?: Journal of Foraminiferal Research, v. 32, p. 97-109.

HOPLEY, D., 1986, Corals and reefs as indicators of palaeo-sea levels, with special reference to the Great Barrier Reef. In: van de Plassche, O. (Ed.), Sea-level 
Research: A Manual for the Collection and Evaluation of Data, Geo Books, Norwich, p. 195-228.

HORTON, B.P., 1999, The contemporary distribution of intertidal foraminifera of Cowpen Marsh, Tees Estuary, UK: implications for studies of Holocene sea-level changes: Palaeogeography, Palaeoclimatology, Palaeoecology Special Issue, v. 149, p. $127-149$.

- and EDWARDS, R.J., 2003, Seasonal distributions of foraminifera and their implications for sea-level studies. SEPM (Society for Sedimentary Geology) Special Publication No. 75, 21-30.

$\longrightarrow$, and -2004 , The application of local and regional transfer functions to reconstruct former sea levels, North Norfolk, England. The Holocene in press.

- , - and LLOYD, J.M., 1999a, UK intertidal foraminiferal distributions: implications for sea-level studies: Marine Micropaleontology, v. 36, p. 205-223.

$\longrightarrow,-$, and,$- 1999 b$, Reconstruction of former sea levels using a foraminiferal-based transfer function. Journal of Foraminiferal Research, v. 29, 117-129.

,-- , and $\longleftarrow$ 2000, Implications of a microfossil transfer function in Holocene sea-level studies. In: Shennan, I. and Andrews, J.E. (Eds.) Holocene land-ocean interaction and environmental change around the western North Sea, Geological Society Special Publication, 166, p. 41-54.

- Larcombe, P., Woodroffe, S. A., Whittaker, J.E., Wright, M.W. and WynN, C., 2003, Contemporary foraminiferal distributions of the Great Barrier Reef coastline, Australia: implications for sea-level reconstructions: Marine Geology. V. 3320, p. 1-19.

JONES, J. R., and Ross, C. A., 1979, Seasonal distribution of foraminifera in Samish Bay, Washington: Journal of Paleontology, 53, 245-257. 
LAMBECK, K., ESAT, T.M., and POTTER, E-K., 2002, Links between climate and sea levels for the past three million years: Nature, v. 419, p. 199-206.

MACNAE, W., 1968, A general account of the fauna and flora of mangrove swamps and forests in the Indo-West-Pacific region: Advances in Marine Biology, v. 6, p. 73270.

MCINTYRE, C., 1997, The Holocene sedimentology and stratigraphy of the inner shelf of the Great Barrier Reef; deposits of buried shorelines: MSc thesis, Department of Earth Sciences, James Cook University of North Queensland, 201 pp.

MitrovicA, J.X., and Peltier, W.R., 1991, On postglacial geoid subsidence over the equatorial oceans: Journal of Geophysical Research, v. 96, p. 20053-20071.

MURRAY, J. W., 1991, Ecology and palaeoecology of benthic foraminifera: Longman Scientific and Technical, Harlow, England, 397 pp.

- 2000, JFR Comment: The enigma of the continued use of total assemblages in ecological studies of benthic foraminifera: Journal of Foraminiferal Research, v. 30 , p. $244-245$.

- , and ALVE, E., 1999, Natural dissolution of modern shallow water benthic foraminifera: taphonomic effects on the palaeoecological record: Palaeoclimatology, Palaeoecology Special Issue, v. 146, p. 195-209.

$\longrightarrow$, and -2000 , Major aspects of foraminifera variability (standing crop and biomass) on a monthly scale in an intertidal zone: Journal of Foraminiferal Research, v. 30, p. 177-191.

- , and BOWSER, S.S. 2000, Mortality, protoplasm decay rate, and reliability of staining techniques to recognize 'living' Foraminifera: a review: Journal of Foraminiferal Research, v. 30 p. 66-70.

NunN, P. D., and Peltier, W.R. 2001, Far-field test of the ICE-4G model of Global isostatic response to deglaciation using empirical and theoretical Holocene sea- 
level reconstructions for the Fiji Islands, Southwestern Pacific: Quaternary Research, v. 55, p. 203-214.

PATTERSON, R. T., 1990, Intertidal benthic foraminifera biofacies on the Fraser River Delta, British Columbia: Micropaleontology, v. 36, p. 229-244.

Peltier, W.R., 2002, On eustatic sea level history: Last Glacial Maximum to Holocene: Quaternary Science Reviews, v. 21, p. 377-396.

- Shennan, I., Drummond, R., and HORTON, B.P., 2002, On the post-glacial isostatic adjustment of the British Isles and the shallow visco-elastic structure of the Earth: Geophysical Journal International, v. 148, p. 443-475.

Plassche, O. VAN DE, 1986, Sea-level Research: A Manual for the Collection and Evaluation of Data, Geo Books, Norwich, 617 pp.

REVETS, S. A., 2000, Foraminifera of Leschenault Inlet: Journal of the Royal Society of Western Australia, v. 83, p. 365-375.

RIJK, S. DE, 1995, Salinity control on the distribution of salt marsh Foraminifera (Great Marshes, Massachusetts): Journal of Foraminiferal Research, v. 25, p. 156-166.

SCHAFER, C.T., 1968, Lateral and temporal variation of foraminiferal populations living in nearshore water areas: Atlantic Oceanographic Laboratory Report, no. 68-4, 27 pp. , and MUDIE, P.J., 1980, Spatial variability of foraminifera and pollen in nearshore sediments, St Georges Bay, Nova Scotia: Canadian Journal of Earth Science, v. 17 , p. $313-324$.

SCOTT, D.K., and LECKIE, R.M., 1990, Foraminiferal zonation of Great Sippwissett Salt Marsh (Falmouth, Massachusetts): Journal of Foraminiferal Research, v. 20, p. 248-266.

ScotT, D.B., and MEDIOLI, F.S., 1978, Vertical zonation of marsh foraminifera as accurate indicators of former sea levels: Nature, v. 272, p. 528-531. 
- , and $-1980 a$, Quantitative studies of marsh foraminifera distribution in Nova Scotia: implications for sea-level studies: Journal of Foraminiferal Research, Special Publication, v. 17, 1-58.

$\longrightarrow$, and $-1980 \mathrm{~b}$, Living vs. total foraminifera populations: their relative usefulness in palaeoecology: Journal of Paleontology, v. 54, p. 814-831.

- - , and SCHAFER, C.T., 2001, Monitoring in coastal environments using foraminifera and thecamoebian indicators: Cambridge University Press, Cambridge, 177pp.

SHENNAN, I., 1986. Flandrian sea-level changes in the Fenland, II: Tendencies of sealevel movement, altitudinal changes and local and regional factors. Journal of Quaternary Science, v. 1, 155-179.

- and HORTON, B.P., 2002, Relative sea-level changes and crustal movements of the UK, Journal of Quaternary Science, v. 16, p. 511-526.

- $\longrightarrow$, INNES, J. B., Lloyd, J. L., McARThuR, J. J., and RUThERFORD, M. M., 2000, Holocene crustal movements and relative sea-level changes on the east coast of England, in Shennan, I. and Andrews, J. E., eds., Holocene land-ocean interaction and environmental change around the western North Sea: Geological Society Special Publication, v. 166, p. 275-299.

—, Peltier, W.R., Drummond, R., and Horton, B.P., 2002, Global to local scale parameters determining relative sea-level changes and the post-glacial isostatic adjustment of Great Britain: Quaternary Science Reviews, v. 21, p. 397-408.

SNEDAKER, S.C., 1982, Mangrove species zonation: why? In: Sen, D.N. and Rajpurohit, K.S. (Eds.) Contributions to the Ecology of Halophytes: The Hague, The Netherlands, p. 111-125.

SPENCER, R.S., 2000, Foraminiferal assemblages from a Virginia saltmarsh, Phillips Creek, Virginia: Journal of Foraminiferal Research, v. 30, 143-155. 
SWALLOW, J.E., 2000, Intra-annual variability and patchiness in living assemblages of salt-marsh foraminifera from Mill Rythe Creek, Chichester Harbour, England: Journal of Micropalaeontology, v. 19, p. 9-22.

Wallace, A.R., [1869] 1962. The Malay Archipelago: The Land of the Orang-utan and the Bird of Paradise. A Narrative of Travel with Studies of Man and Nature: Macmillan, London. Reprint: Dover Publications, New York.638pp.

WALTON, W. R., 1952, Techniques for recognition of living foraminifera: Contributions from Cushman Foundation for Foraminiferal Research, v. 3, p. 56-60.

WANG, P., and CHAPPELL, J., 2001, Foraminifera as Holocene environmental indicators in the South Alligator River, Northern Australia: Quaternary International. v. 83-85.

YASSINI, I., and JONES, B. G., 1995, Foraminiferida and ostracoda from estuarine and shelf environments on the southeastern coast of Australia: University of Wollongong Press, Wollongong, 484 pp.

Yokoyama, Y., Purcell, A. Lambeck, K., and Johnston, P., 2001, Shore-line reconstruction around Australia during the Last Glacial Maximum and Late Glacial Stage: Quaternary International, v. 83-85, p. 9-18. 


\section{TABLES}

Table 1. T-Test to determine whether two samples (from A1 and A2, A1 and B) are likely to have come from the same two underlying populations and thus assess temporal and spatial influences. Values in bold exceed the $p<0.05$ significance value (2.09) and indicate rejection of the null hypothesis that the $A 1$ and $A 2$, and $A 1$ and $B$ are equal.

Table 2. Indicative range and reference tide level for faunal zones of the mangroves of Kaledupa. 
Table 1

\begin{tabular}{lllll}
\hline & \multicolumn{2}{l}{ Temporal (A1 and A2) } & \multicolumn{2}{l}{ Spatial (A1 and B) } \\
\hline Species & Live & Dead & Live & Dead \\
Quinqueloculina spp. & $\mathbf{2 . 9 4}$ & 1.82 & $\mathbf{5 . 5 1}$ & 0.54 \\
Ammonia tepida & 0.92 & 0.20 & 1.66 & 2.00 \\
Elphidium advenum & $\mathbf{3 . 1 0}$ & 0.09 & 2.08 & 0.54 \\
Discorbinella bertheloti & 0.84 & 1.15 & 1.19 & 0.79 \\
Trochammina inflata & 0.82 & 0.64 & 0.39 & 0.62 \\
Miliammina fusca & 1.02 & 0.28 & $\mathbf{2 . 3 8}$ & 0.55 \\
Arenoparrella mexicana & 1.97 & 0.22 & $\mathbf{2 . 2 0}$ & 0.93 \\
\hline
\end{tabular}


Table 2.

\begin{tabular}{lclc}
\hline & Indicative & Reference Water Level & Reference Water Level \\
& Range & & $(\mathrm{m} \mathrm{IHD})$ \\
\hline Zone D-la & $\pm 10 \mathrm{~cm}$ & MHHW & $1.92 \mathrm{~m}$ \\
Zone D-I directly & $\pm 4 \mathrm{~cm}$ & MHHW $-6 \mathrm{~cm}$ & $1.86 \mathrm{~m}$ \\
above Zone D-lb & & & $1.75 \mathrm{~cm}$ \\
Zone D-Ib & $\pm 15 \mathrm{~cm}$ & {$[$ MHHW + MLHW]/2 - 3 cm } & $1.66 \mathrm{~cm}$ \\
Zone D-lb directly & $\pm 6 \mathrm{~cm}$ & MLHW $-6 \mathrm{~cm}$ & \\
above Zone D-II & & & $1.09 \mathrm{~cm}$ \\
Zone D-II & & & \\
\hline
\end{tabular}




\section{FIGURES}

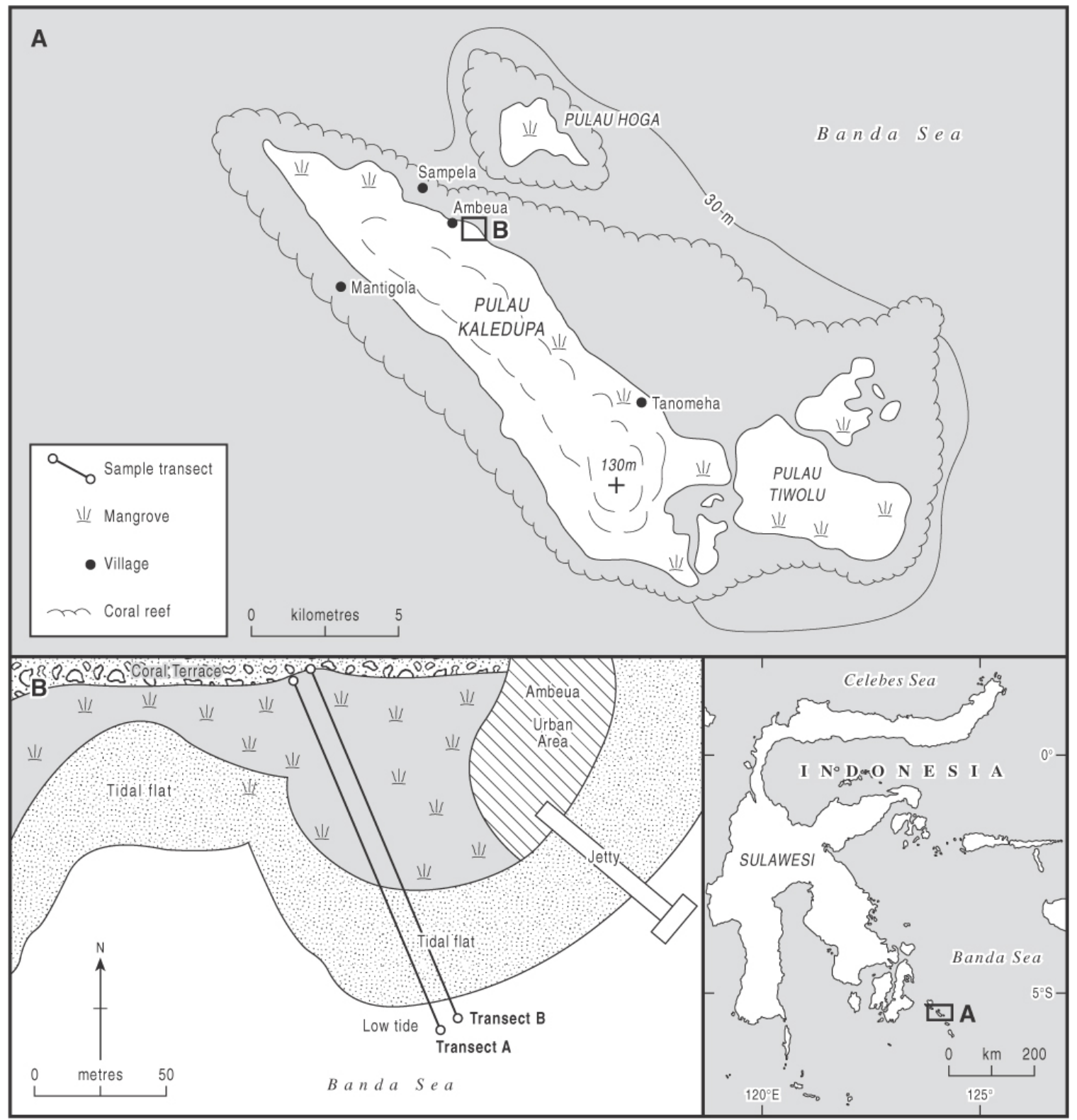

Figure 1

Location map of study area. (A) Kaledupa, Wakatobi Marine National Park, (B)

Transects A and B on a tidal mangrove creek and (C) Sulawesi, Indonesia. 


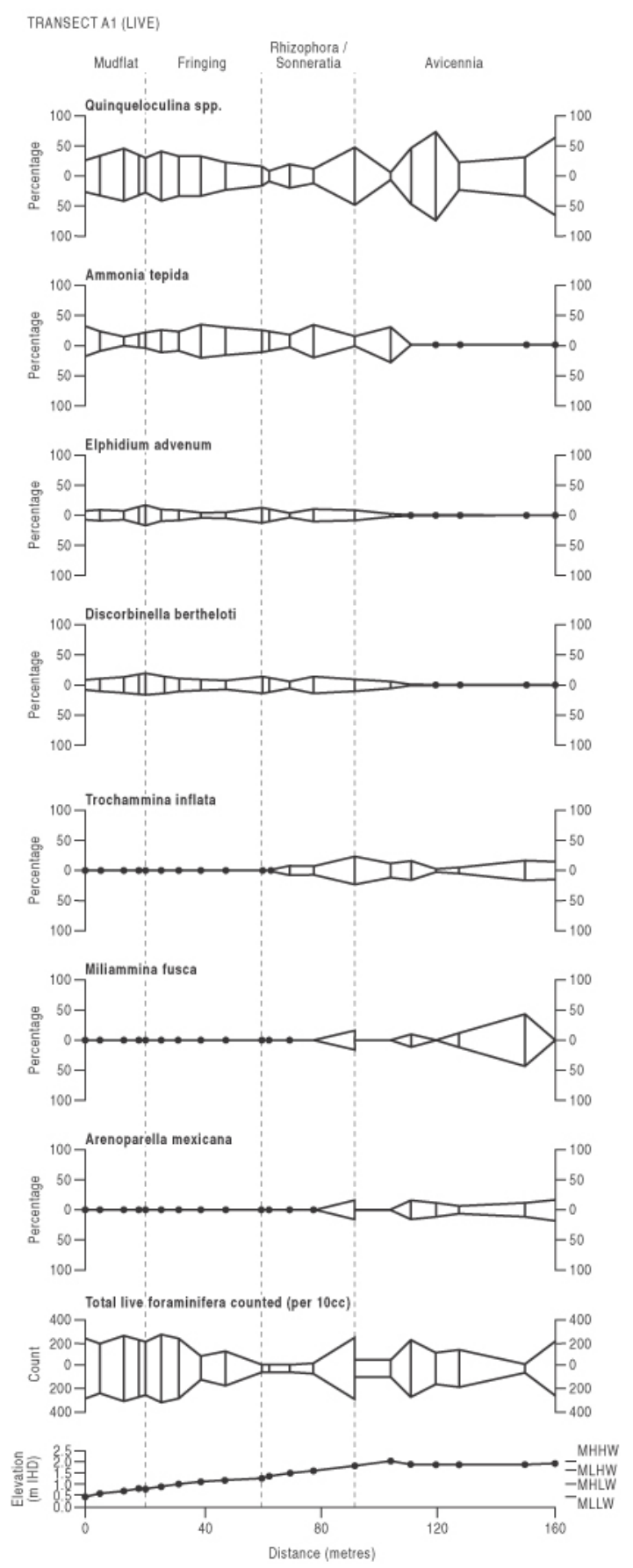

Figure 2 Live foraminiferal abundance (\%) of seven foraminiferal species and foraminiferal populations of the mangroves of Kaledupa Transect A1. The elevation, tidal levels (mean high high water (MHHW), mean low high water (MLHW) and mean high low water (MHLW) and mean low low water (MLLW) and floral zonation are indicated. 


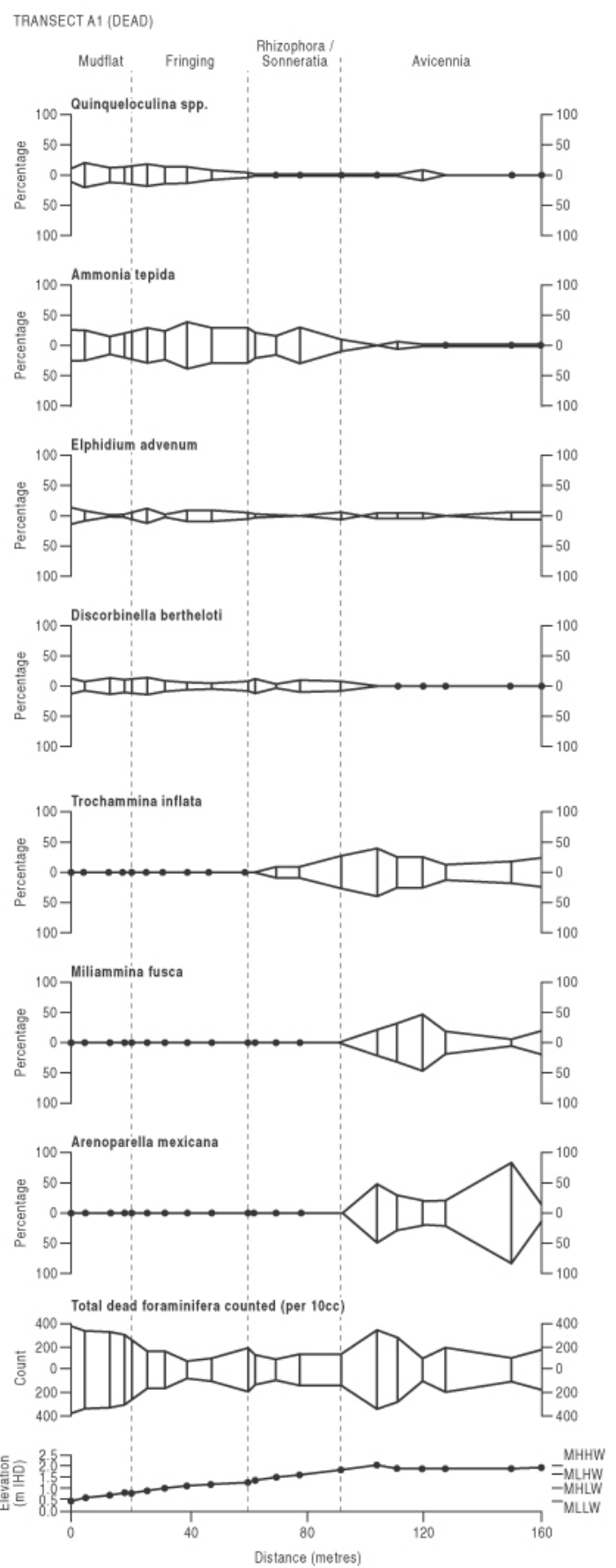

Figure 3 Live foraminiferal abundance (\%) of seven foraminiferal species and foraminiferal populations of the mangroves of Kaledupa Transect A2. The elevation, tidal levels (mean high high water (MHHW), mean low high water (MLHW) and mean high low water (MHLW) and mean low low water (MLLW) and floral zonation are indicated. 


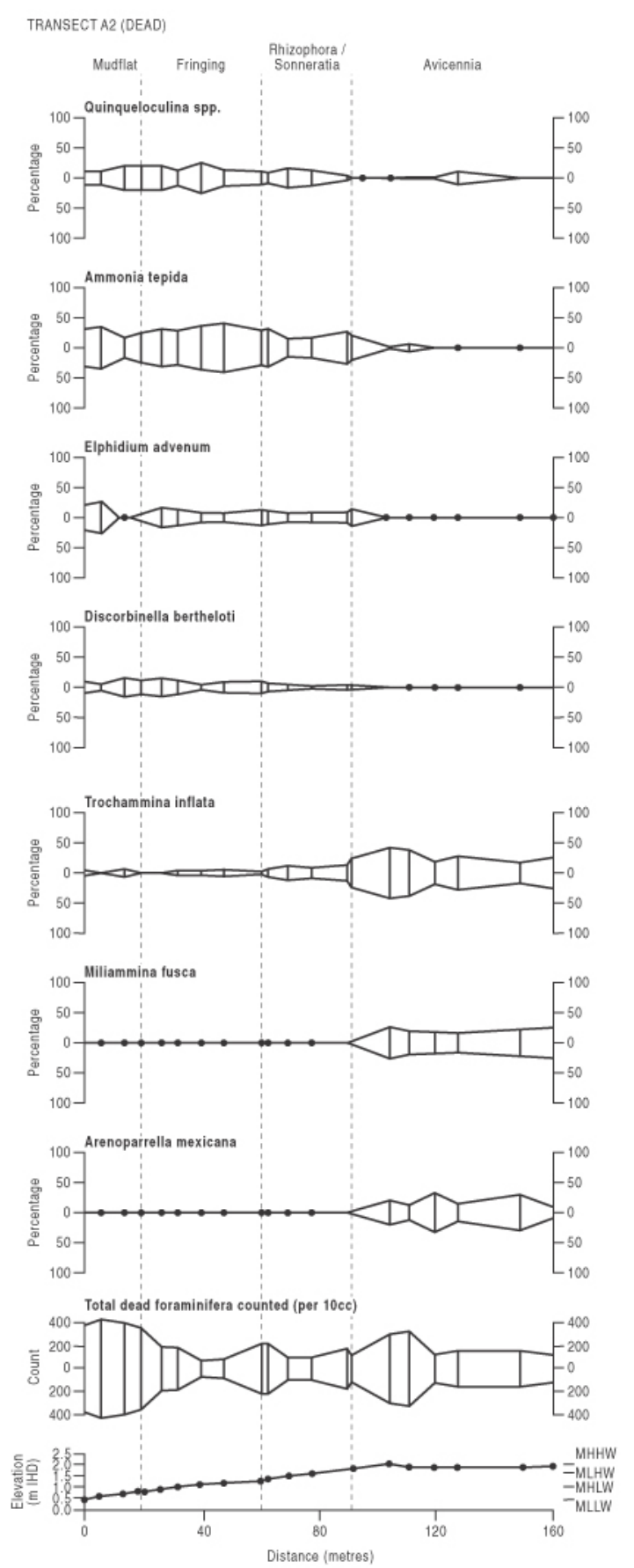

Figure $4 \quad$ Live foraminiferal abundance (\%) of seven foraminiferal species and foraminiferal populations of the mangroves of Kaledupa Transect B. The elevation, tidal levels (mean high high water (MHHW), mean low high water (MLHW) and mean high low water (MHLW) and mean low low water (MLLW) and floral zonation are indicated. 


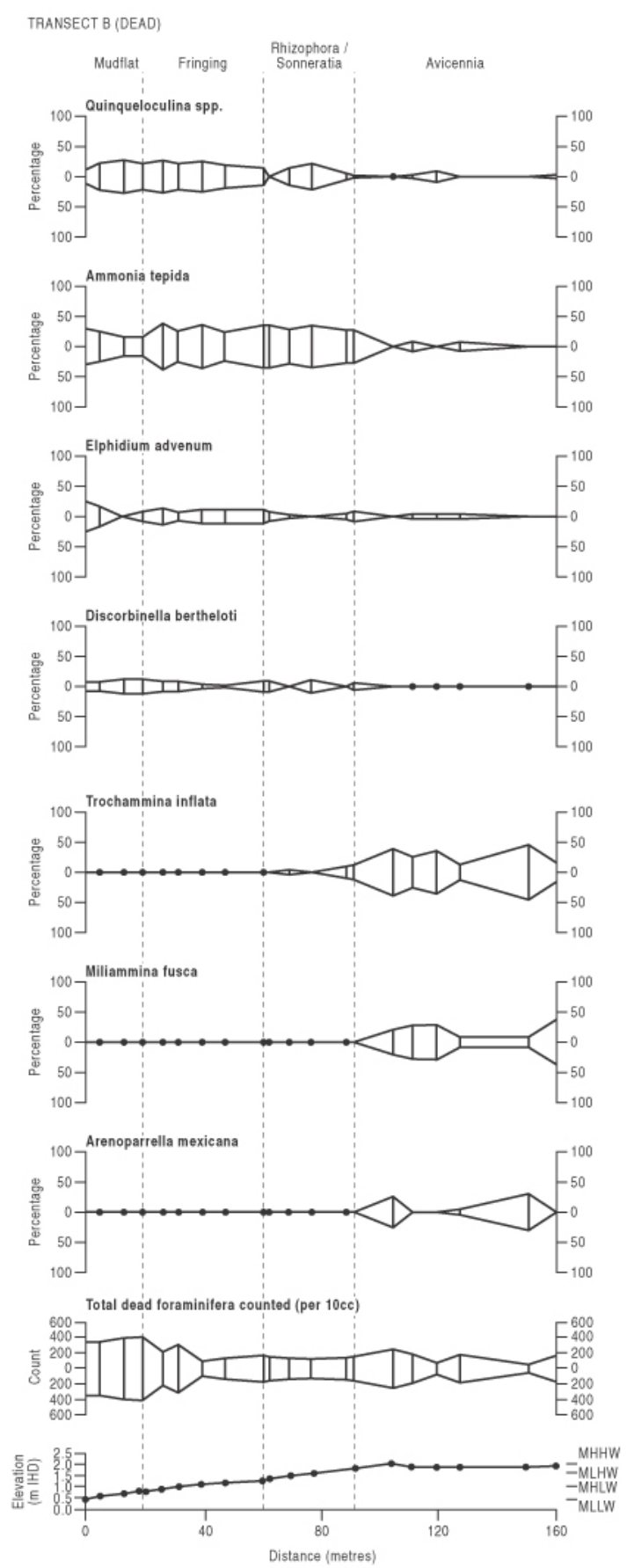

Figure 5 Dead foraminiferal abundance (\%) of seven foraminiferal species and foraminiferal populations of the mangroves of Kaledupa Transect A1. The elevation, tidal levels (mean high high water (MHHW), mean low high water (MLHW) and mean high low water (MHLW) and mean low low water (MLLW) and floral zonation are indicated. 


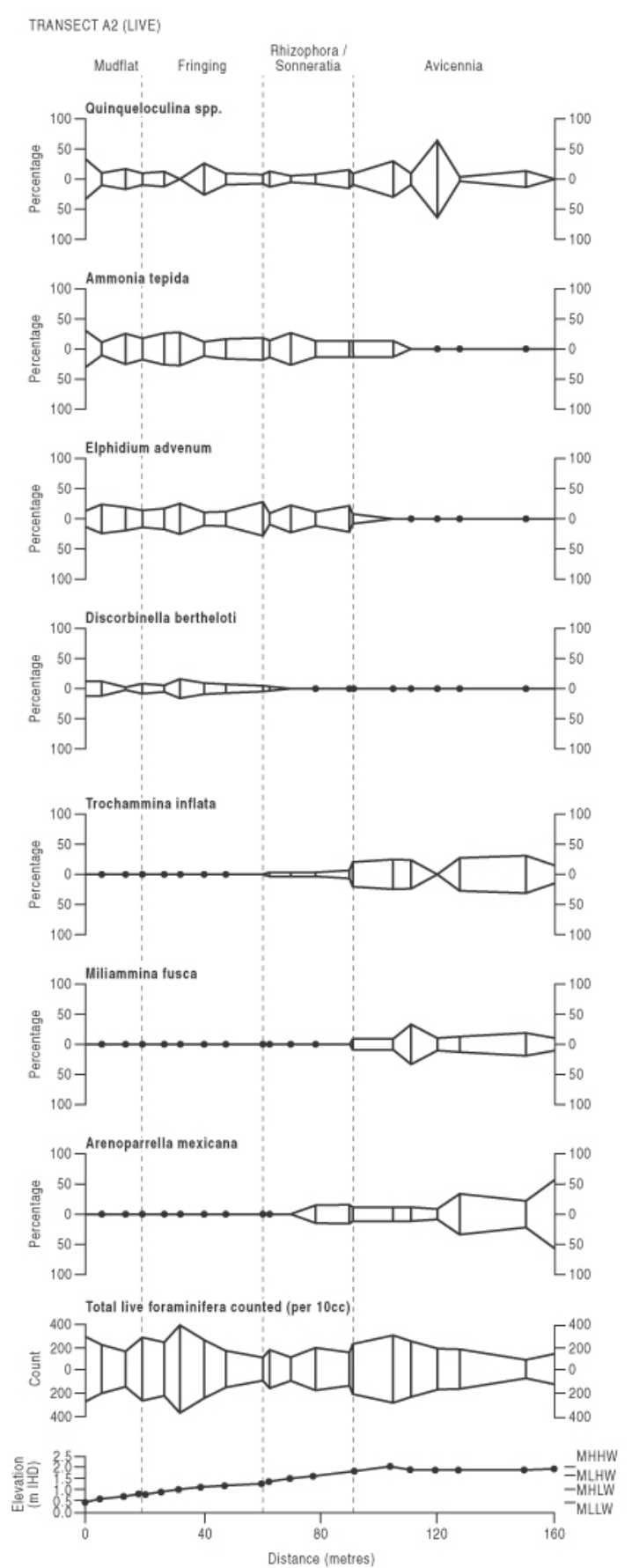

Figure 6 Dead foraminiferal abundance (\%) of seven foraminiferal species and foraminiferal populations of the mangroves of Kaledupa Transect A2. The elevation, tidal levels (mean high high water (MHHW), mean low high water (MLHW) and mean high low water (MHLW) and mean low low water (MLLW) and floral zonation are indicated. 


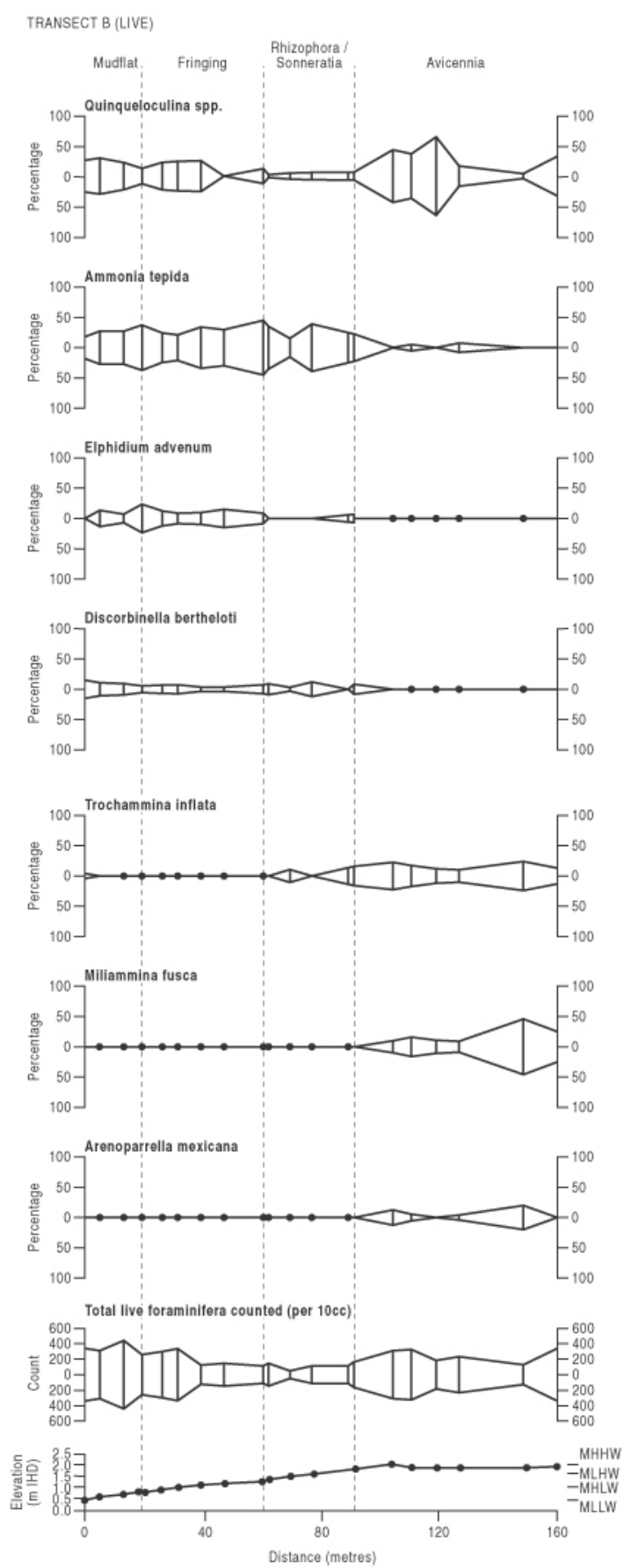

Figure 7 Dead foraminiferal abundance (\%) of seven foraminiferal species and foraminiferal populations of the mangroves of Kaledupa Transect B. The elevation, tidal levels (mean high high water (MHHW), mean low high water (MLHW) and mean high low water (MHLW) and mean low low water (MLLW) and floral zonation are indicated. 

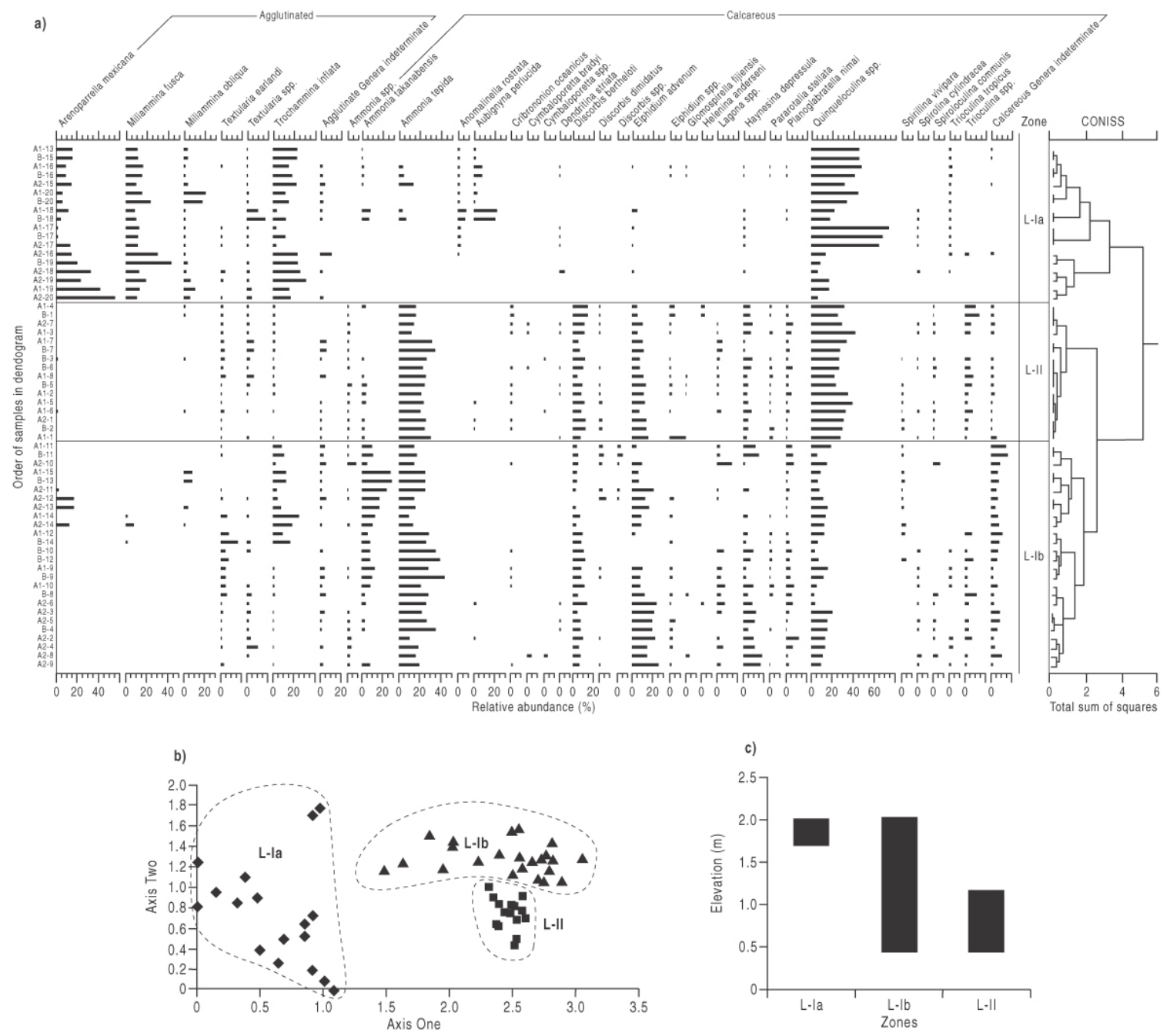

Figure 8 (a) Unconstrained cluster analysis based on unweighted Euclidean distances showing the live foraminiferal assemblages versus order of samples on dendrogram, (b) detrended correspondence analysis and (c) vertical zonation of the mangroves of Kaledupa transects A1, A2 and B. Only samples with counts greater than 40 individuals and species which reach $2 \%$ of the total sum are included. 


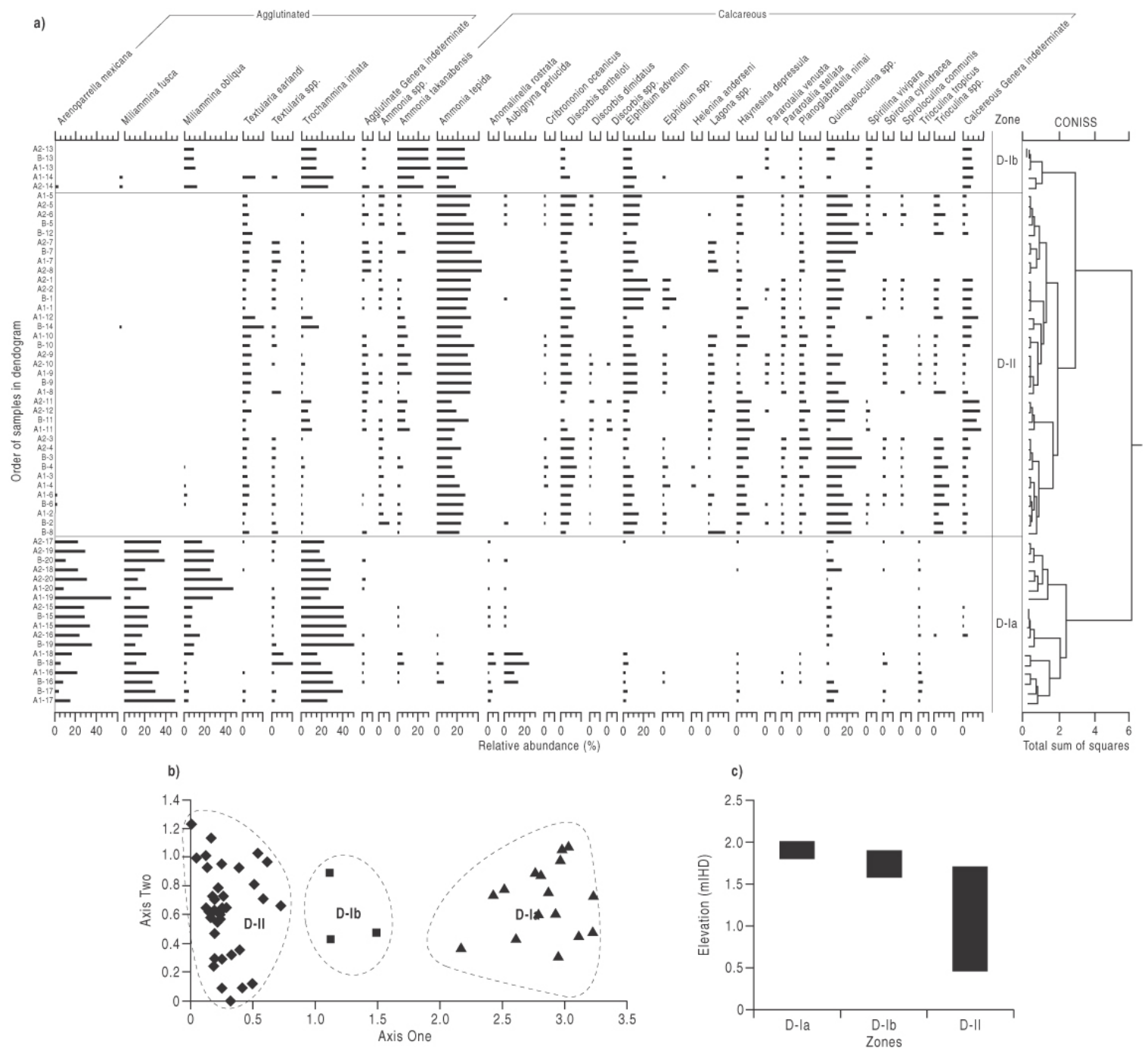

$\begin{array}{ll}\text { Figure } 9 & \text { (a) Unconstrained cluster analysis based on unweighted Euclidean distances }\end{array}$ showing the dead foraminiferal assemblages versus order of samples on dendrogram, (b) detrended correspondence analysis and (c) vertical zonation of the mangroves of Kaledupa transects $A 1, A 2$ and B. Only samples with counts greater than 40 individuals and species which reach $2 \%$ of the total sum are included. 


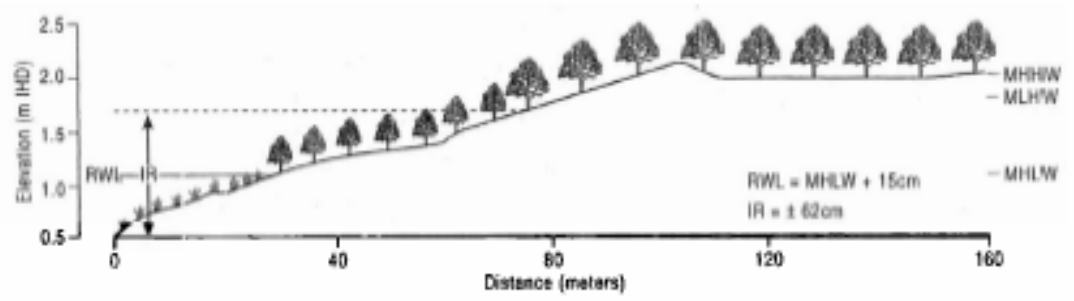

Figure 10 The indicative meaning of the mangroves of Kaledupa illustrating the indicative range (IR) and reference water level (RWL) for Zone D-II. Mean high high water (MHHW), mean low high water (MLHW) and mean high low water (MHLW) are shown.

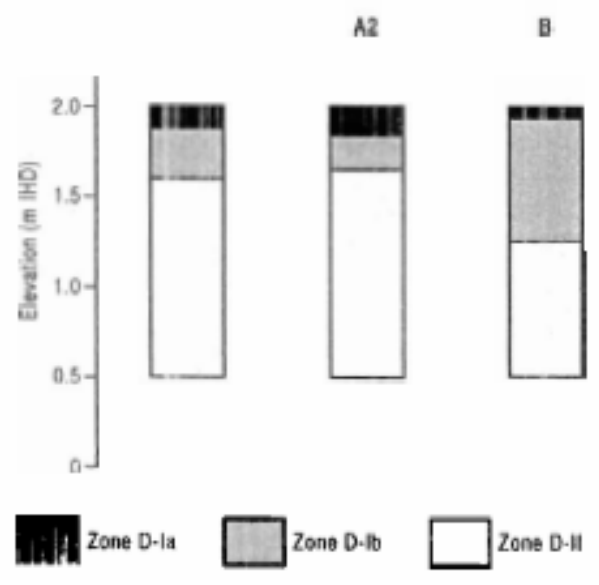

Figure 11 Vertical zonations of the Transects A1, A2 and B of the mangroves of Kaledupa determined by unconstrained cluster analysis based on unweighted Euclidean distance and detrended correspondence analysis of relative abundances of dead individuals. Only samples with counts greater than 40 individuals and species which reach $2 \%$ of the total sum are included. 

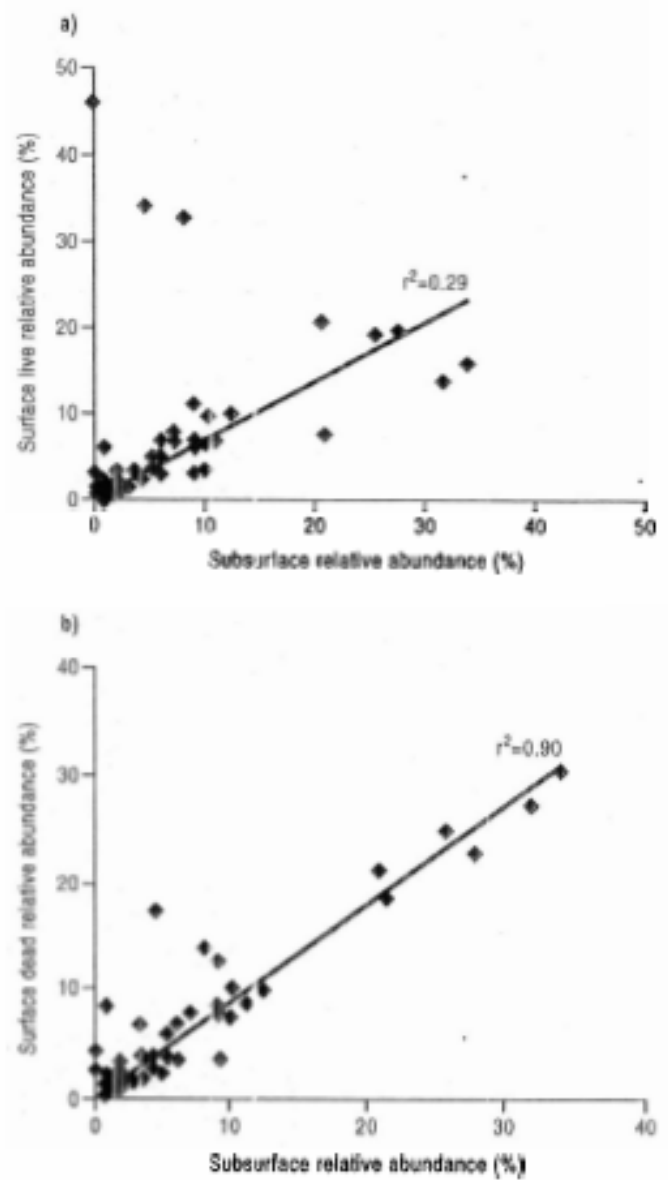

Figure 12 Scatter plots and $r^{2}$ showing the relationship between (a) live and (b) dead surface and subsurface foraminiferal assemblages (\%) from the mangroves of Kaledupa.

\section{PLATE 1}

1. Miliammina fusca (Brady). a. side view, X136. b. oblique apertural view, X176. c. side view, X176. 2. Miliammina oblique (Heron-Allen and Earland). a. side view, X200. b. apertural view, X200. 3. Arenoparrella mexicana (Anderson). a. side view, X200. b. oblique apertural view, X200. 4. Trochammina inflata (Montagu). a. side view, X176. b. 
side view, X176. c. edge view, X176. d. oblique apertural view, X176. 5. Discorbinella bertheloti (d'Orbigny). a. spiral view, X200. b. apertural view, X200. 6. Haynesina depressula (Walker and Jacob). a. side view, X200. b. edge view, X200. 7. Elphidium advenum (Cushman). a. side view, X200. b. edge view, X200. 8. Ammonia tepida (Cushman). a. spiral view, X200. b. apertural view, X200. 9. Ammonia takanabensis (Ishizaki). a. spiral view, X200. b. apertural view, X200. 


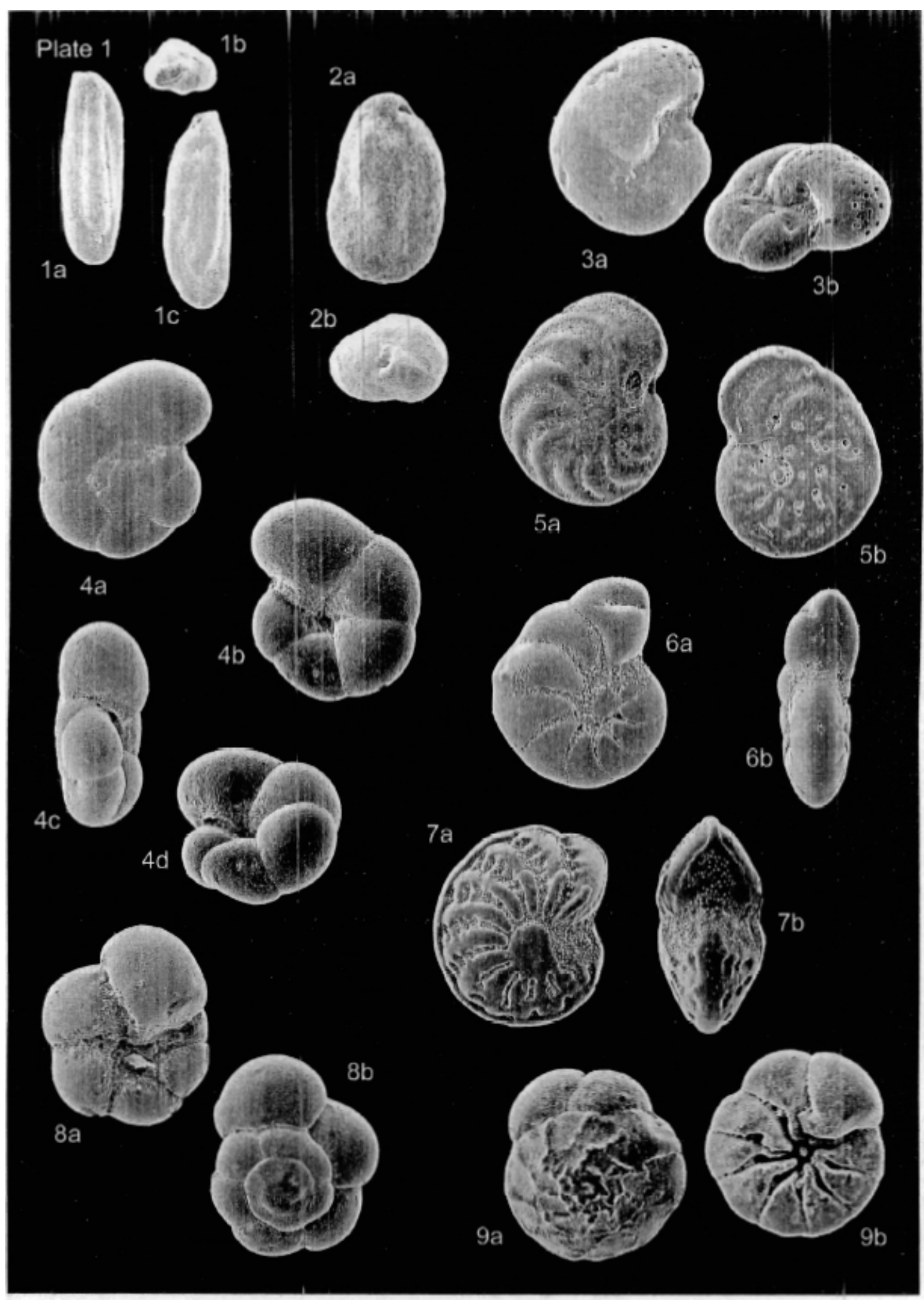

